\title{
PENERAPAN PIJAT PERUT SEBAGAI EVIDENCE BASED NURSING UNTUK MENURUNKAN VOLUME RESIDU LAMBUNG PADA PASIEN KRITIS
}

\author{
Wahyu Rahmawati ${ }^{1, *}$, Beti Kristinawati ${ }^{2}$, Kurniasari ${ }^{3}$ \\ Universitas Muhammadiyah Surakarta \\ 1j230195012@student.ums.ac.id*
}

\begin{abstract}
Abstrak
Latar Belakang : Pasien kritis yang dirawat di ruang perawatan intensif menghadapi beberapa masalah pencernaan akibat stress, peningkatan volume residu, diare, sembelit, dan kekurangan gizi. Pemberian nutrisi nasogastrik memiliki risiko khususnya pada pasien kritis. Komplikasi akibat ketidaktepatan dalam pemberian enteral diantaranya adalah nausea dan muntah yang disebabkan karena penundaan pengosongan lambung, posisi baring pasien selama pemberian nutrisi dan efek samping dari obat-obatan selama di ruang perawatan intensif.

Tujuan : Penerapan hasil penelitian pijat perut ini bertujuan untuk menurunkan volume residu lambung pada pasien- pasien kritis yang terpasang nasogastric tube.

Metode : Teknik pengambilan sampel secara purposive sampling. Analisis data menggunakan distribusi frekuensi. Sumber data diambil dari 10 jurnal internasional yang menjelaskan tentang pijat perut untuk mengurangi jumlah volume residu lambung. Intervensi pijat perut menggunakan baby oil dilakukan pada 7 orang pasien kritis yang dirawat di ruang ICU dan dipilih berdasarkan kriteria yang telah ditentukan. Tindakan pijat perut dilakukan dua kali sehari dengan durasi 20 menit selama 3 hari dan selanjutnya dilakukan evaluasi.

Hasil : 7 sampel yang dilakukan pijat perut mengalami penurunan volume residu lambung rata-rata 85,00 cc $(43,49 \%)$ dihari ketiga dengan rata-rata Gastric Residue Volume (GRV) pre hari ke-1 130,71 cc $(63,27 \%)$. Dan GRV post hari ke1111,43 cc $(42,98 \%)$.

Simpulan: Pijat perut dapat diaplikasikan pada pasien dengan kondisi kritis yang terpasang nasogastric tube untuk menurunkan jumlah volume residu lambung.

Kata kunci: Pijat perut; Volume Residu Lambung; Pasien Kritis

\section{THE APPLICATION OF ABDOMINAL MASSAGE AS EVIDENCE BASED NURSING TO REDUCE THE VOLUME OF GASTRIC RESIDUE IN CRITICAL PATIENTS}

\begin{abstract}
Background: Critical patients treated in intensive care rooms face several digestive problems due to stress, increased residual volume, diarrhea, constipation, and malnutrition. The provision of nasogastric nutrition carries a risk especially in critically ill patients. Complications due to inaccurate enteral administration include nausea and vomiting caused by delays in emptying the
\end{abstract}


stomach, lying in the patient's position during nutrition and side effects from medications while in the intensive care room.

The Purpose : The application of the results of this abdominal massage study aims to reduce the volume of gastric residue in critically ill patients with nasogastric tubes.

Method: The sampling technique was purposive sampling. Data analysis uses frequency distribution. Data sources are taken from 10 international journals that explain abdominal massage to reduce the amount of gastric residual volume. The intervention of abdominal massage using baby oil was carried out on 7 critical patients who were treated in the ICU and selected based on predetermined criteria. The act of abdominal massage is done twice a day with a duration of 20 minutes for 3 days and then evaluated.

Result: 7 samples of abdominal massage experienced a decrease in gastric residual volume by an average of $85,00 \mathrm{cc}(43,49 \%)$ on the third day with an average gastric residual volume (GRV) pre day 1 130,71 cc (63,27\%) and GRV post day 1111,43 cc $(42,98 \%)$.

Conclusion: Abdominal massage can be applied to patients with critical conditions with nasogastric tubes attached to reduce the amount of gastric residual volume.

Key words: Abdominal Massage; Gastric Residue Volume; Critical Patient

\section{PENDAHULUAN}

Pasien kritis menurut AACN (American Association of Critical Care Nursing, 2010) didefinisikan sebagai pasien yang berisiko tinggi untuk masalah kesehatan aktual ataupun potensial yang mengancam jiwa (AACN, 2010). Pasienpasien kritis yang dirawat di ruang perawatan intensif menghadapi beberapa masalah pencernaan akibat stress, peningkatan volume residu, diare, sembelit, dan kekurangan gizi (Gacoin A et al, 2010).

Pasien kritis yang mendapat nutrisi enteral melalui nasogastrik memiliki banyak keuntungan. Pemberian nutrisi nasogastrik pada pasien kritis juga memiliki kemungkinan komplikasi akibat ketidaktepatan dalam pemberian nurisi diantaranya retensi lambung, aspirasi paru, nausea, muntah. Kemungkinan penyebabnya adalah karena penundaan pengosongan lambung, posisi baring pasien selama pemberian nutrisi, peningkatan kecepatan, volume dan konsentrasi. Untuk meningkatkan toleransi makan dan mengurangi residu lambung, salah satu pengobatan non-farmakologi pada pasien kritis yang dapat menurunkan volume residu lambung ialah terapi pijat, tepatnya pijat pada bagian perut. Jenis-jenis pengobatan komplementer mulai diaplikasikan dan telah dipertimbangkan terutama di peduli paliatif khususnya pijat perut. Pijat adalah metode terapi dengan sejarah panjang dalam pengobatan dan itu sebagian besar digunakan pada akhir abad 19 dan awal abad 20 (Dehghan M et al, 2017). Pijat adalah metode terapi dengan sejarah panjang dalam pengobatan. Beberapa ratus tahun yang lalu, penggunaan massage perut diakui sebagai metode efektif untuk mengurangi sembelit dan meningkatkan motilitas sistem pencernaan (Uysal N, 2017). 
Pijat perut adalah adalah salah satu jenis terapi komplementer yang mampu mencegah dan mengurangi gangguan pada sistem gastrointestinal (Kahraman \& Ozdemir, 2015). Mekanisme kerja perut adalah menurunkan kontraksi dan tegangan pada otot abdomen, meningkatkan motilitas pada sistem pencernaan, meningkatkan sekresi pada sistem intestinal serta memberikan efek pada relaksasi sfringter sehingga mekanisme kerja tersebut akan mempermudah dan memperlancar pengeluaran feses (Sinclair, 2011). Selain itu, pijat perut ditemukan berpengaruh terhadap isu-isu motilitas, seperti peningkatan volume residual lambung dan distensi abdomen pada pasien dengan makanan enteral (Uysal et al, 2012) sehingga berguna mengurangi resiko aspirasi atau residu lambung (Lamas et al, 2010).

Berdasarkan analisa situasi di Ruang ICU RSUD Kabupaten Sukoharjo selama 6 hari pada tanggal 18 - 23 November 2019, terdapat 8 bed dengan jumlah pasien paling banyak dengan diagnosa STEMI, NSTEMI, Gagal nafas, dll. Beberapa pasien terpasang NGT untuk memenuhi kebutuhan nutrisi atau mengukur residu lambung. Misalnya pada tanggal $18-23$ November terdapat 4 pasien dari 9 pasien (45\%) yang terpasang NGT. Setiap sebelum pemberian nutrisi enteral, dilakukan aspirasi ntuk pengecekan jumlah residu lambung. Didapatkan 2 dari 4 pasien yang terpasang NGT jumlah residu lambung $>100 \mathrm{cc}$.

Hasil beberapa penelitian sebelumnya menunjukkan bahwa beberapa studi meneliti efek dari pijat perut pada fungsi pencernaan. Kebanyakan dari mereka berfokus pada sembelit dan volume residu. Oleh karena itu, penerapan evidence based nursing pijat perut ini dilakukan untuk menyelidiki efek pijat perut pada pasien kritis untuk menurunkan atau mengurangi jumlah volume residu lambung.

\section{METODE}

Teknik pengambilan sampel secara purposive sampling. Analisis data menggunakan distribusi frekuensi. Sumber data diambil dari 10 jurnal internasional yang menjelaskan tentang pijat perut untuk mengurangi jumlah volume residu lambung dengan menggunakan kata kunci dari abdominal massage, gastric residual volume, intensive care unit, enteral feeding. Kemudian dipilih salah satu jurnal yang dipakai untuk dijadikan rujukan dan jurnal lain sebagai pendukung.

Penerapan aplikasi jurnal dilakukan di ruang ICU RSUD kabupaten Sukoharjo pada 7 pasien dari bulan November sampai Desember tahun 2019. Pijat menggunakan baby oil dilakukan sehari 2 kali selama 3 hari dengan waktu 20 menit. Bahan utama yang dibutuhkan dalam pengaplikasian pijat perut adalah baby oil. Kriteria inklusi: pasien terpasang NGT (Nasogastric Tube), GCS (Glasgow Coma Scale) pasien < 7, tidak ada radioterapi perut dalam 6 minggu terakhir. Kriteria eksklusi: pasien yang mendapat obat prokinetik seperti domperidone, cisapride dan lain-lain, pasien pasca bedah perut, pasien pulang/meninggal.

Teknik pengumpulan data, Tahap awal dilakukan pengukuran residu awal dengan dibilas kemudian jumlah residu diukur dan dicatat, lalu residu dimasukkan kembali. Tahap berikutnya pijat perut dilakukan selama 20 menit, setelah pijat makanan enteral melalui NGT dimasukkan sampai jumlahnya meningkat $300 \mathrm{ml}$ 
jika ditambahkan dengan jumlah residu yang diukur sebelumnya. Setelah 2 jam, tahap berikutnya dilakukan pijat perut yang kedua dan akhirnya 1 jam setelah pijat kedua dilakukan pengukuran volume residu lambung kembali. Teknik pijatnya, tahap pertama pijatan dimulai dengan gerakan seperti menyikat kulit di daerah perut menggunakan telapak tangan, dilakukan selama 4 menit, tahap kedua deformitas elastis dari fasia torakolumbalis dalam bentuk perpindahan yaitu dengan cara tangan yang dominan ditempatkan pada kulit perut dan tangan lainnya diletakkan diatas tangan yang dominan kemudian tekan bagian bawah kulit seperti diperas, dilakukan selama 4 menit, tahap ketiga kulit perut diambil dan diremas oleh jari seperti menguleni adonan, dilakukan selama 4 menit, tahap keempat gerakan goyang atau kejut di sepanjang ketiak dari atas ke bawah, dilakukan selama 4 menit, Tahap kelima jari-jari ditempatkan antara ruang interkostal dan menarik kulit dengan tekanan yang sesuai atau tepat selama 4 menit.

\section{HASIL DAN PEMBAHASAN}

Tabel 1. Distribusi Karakteristik Pasien ICU

\begin{tabular}{ccccc}
\hline No & Variabel & Item & Jumlah & \% \\
\hline \multirow{2}{*}{1} & \multirow{2}{*}{ Jenis Kelamin } & Laki-laki & 5 & $71,4 \%$ \\
& \multirow{3}{*}{2} & Perempuan & 2 & $28,6 \%$ \\
& \multirow{2}{*}{ Usia } & $<45$ tahun & 1 & $14,3 \%$ \\
\multirow{2}{*}{3} & \multirow{2}{*}{ Jumlah hari dirawat } & $>45$ tahun & 6 & $85,7 \%$ \\
& & $>5$ hari & 5 & $71,4 \%$ \\
& & $>5$ hari & 2 & $28,6 \%$ \\
\hline
\end{tabular}

Berdasarkan Tabel 1 menunjukkan karakteristik dari 7 pasien, 5 orang $(71,4 \%)$ berjenis kelamin laki-laki, usia lebih dari 45 tahun ada 6 orang $(85,7 \%)$, jumlah hari dirawat paling banyak kurang dari 5 hari ada 5 orang $(71,4 \%)$.

Tabel 2. Hasil Pijat Perut Selama 3 Hari Penerapan

\begin{tabular}{cccc}
\hline Pre Test GRV sebelum pijat Hari 1 & \multicolumn{3}{c}{ Post Test GRV } \\
\cline { 2 - 4 }$(\mathbf{c c}) \%$ & Hari 1 (cc) \% & Hari 2 (cc) \% & Hari 3 (cc) \% \\
\hline $130,71(63,27)$ & $111,43(42,98)$ & $102,86(52,9)$ & $85,00(43,49)$ \\
\hline
\end{tabular}

Berdasarkan Tabel 2 menunjukkan setelah dilakukan pijat perut selama 3 hari berturut- berturut pada 7 pasien, ada penurunan jumlah volume residu lambung rata-rata pada pasien $85,00 \mathrm{cc}(43,49 \%)$ dihari ketiga dengan rata-rata GRV pre hari ke-1 130,71 cc $(63,27 \%)$. Dan GRV post hari ke-1 111,43 cc $(42,98 \%)$.

Berdasarkan Tabel 1 dapat dilihat bahwa menurut karakteristik pasien dari 7 pasien, 5 orang $(71,4 \%)$ berjenis kelamin laki-laki, usia lebih dari 45 tahun ada 6 orang $(85,7 \%)$, jumlah hari dirawat paling banyak kurang dari 5 hari ada 5 orang $(71,4 \%)$. Penerapan aplikasi jurnal yang sudah dilakukan, didapatkan bahwa usia paling banyak di atas 45 tahun $(85,7 \%)$. Dalam penelitian Setianingsih, et al (2016) yang menganalisis faktor-faktor yang berhubungan dengan GRV pada pasien ICU yang mendapat nutrisi enteral, didapatkan faktor usia memiliki peran 
minimal terhadap GRV. Melihat karakteristik usia pasien ICU RSUD Kabupaten Sukoharjo yang mendapatkan penerapan aplikasi jurnal yaitu > 45 tahun 4 diantaranya adalah lansia. Penelitian yang dilakukan Munawaroh S, et al (2012) menyebutkan bahwa lansia memiliki pengaruh terhadap peningkatan nilai GRV karena mengalami proses menua sehingga saraf-saraf yang mempersarafi saluran cerna misalnya saraf simpatis mengalami gangguan sehingga menurunkan gerakan motilitas lambung, melemahnya gerakan lambung menyebabkan gangguan atau keterlambatan dalam pengosongan lambung.

Gastro Residu Volume (GRV) merupakan volume cairan yang tersisa di perut pada suatu titik selama pemberian nutrisi enteral. Perawat menarik cairan ini melalui nasogastic tube dan spuit $50 \mathrm{cc}$ untuk mengukur jumlah residu, cairan residu yang kurang dari $100 \mathrm{ml}$ akan diganti dengan nutrisi enteral untuk mencegah ketidakseimbangan elektrolit dan kehilangan nutrisi (Theresa, 2010).

Pemantauan GRV adalah untuk menilai keamanan makanan enteral. Ada banyak keuntungan dalam pemantauan GRV diantaranya adalah menurunkan angka kesakitan dan kematian pada pasien kritis, mencegah intoleransi lambung, dan yang paling penting adalah untuk meningkatkan makan (Weijs PJ et al, 2014). Volume lambung yang banyak akan menyebabkan distensi lambung sehingga menimbulkan reflek enterogastrik dari duodenum pada pilorus yang akan memperlambat pengosongan lambung. Pasien yang lemah dengan pengosongan lambung yang buruk dan gangguan menelan serta gangguan mekanisme batuk mempunyai resiko terjadi aspirasi (Munawaroh S et al, 2012).

Tabel 2 menunjukkan setelah dilakukan pijat perut selama 3 hari berturutberturut pada 7 pasien, ada penurunan jumlah volume residu lambung rata-rata pada pasien $85,00 \mathrm{cc}(43,49 \%)$ dihari ketiga dengan rata-rata GRV pre hari ke-1 $130,71 \mathrm{cc}(63,27 \%)$. Dan GRV post hari ke-1 111,43 cc (42,98\%). Hal ini sesuai dengan penelitian yang dilakukan oleh Thomas. SS, et al (2019) bahwa pijat perut telah terbukti menjadi teknik yang efektif dalam mengurangi volume residu lambung pada pasien khususnya yang terpasang naso gastric tube. Dalam penelitian tersebut didapatkan hasil ada perubahan signifikan dalam volume residu lambung $(\mathrm{p}=<0,001)$.

Pijat perut merupakan salah satu terapi komplementer yang dapat diterapkan untuk meningkatkan fungsi sistem pencernaan. Pijat perut mempercepat peristaltik dengan mengubah tekanan intra abdomen dan menciptakan efek mekanik dan reflektif pada usus, mengurangi distensi abdomen dan meningkatkan gerakan usus (Tekgunduz K et al, 2014).

Selain itu penelitian D. McClurg. S, et al (2011) menyebutkan bahwa distensi abdomen banyak terjadi pada pasien yang menerima nutrisi enteral, setelah dilakukan pijat perut distensi abdomen mengalami penurunan. Hal ini terjadi karena pijat perut membantu mempercepat aliran darah dan gerakan peristaltik, menginduksi penyerapan nutrisi dan membantu absorbsi nutrisi ke seluruh usus.

Dalam jurnal Uysal N (2017) juga memaparkan bahwa pijat perut pada pasien yang diberikan makan melalui tabung nasogastrik mencegah volume residu yang besar dan distensi abdomen, serta merangsang sistem pencernaan dan gerakan usus. Sedangkan dalam penelitian lain intervensi yang dilakukan dalam 
penelitiannya menciptakan stimulasi dan sedikit tekanan pada daerah epigastrium dan dengan demikian mendorong gerakan dari sistem pencernaan dan menyebabkan pengosongan gas lambung, sehingga mencegah muntah, distensi abdomen pada pasien, mengosongkan perut dan mengurangi sisa volume lambung pada pasien (Mohammadpour A, 2018).

\section{SIMPULAN}

Penerapan aplikasi jurnal pijat perut yang dilakukan pada pasien kritis yang terpasang NGT (Nasogastric Tube) dengan jumlah volume residu lambung berlebih, efektif mengurangi atau menurunkan jumlah volume residu lambung dan bisa diaplikasikan langsung pada pasien-pasien kritis.

\section{SARAN}

Bagi Tenaga Kesehatan dari hasil penelitian ini diharapkan untuk menerapkan pijat perut sebagai salah satu tindakan mandiri perawat dalam mengurangi jumlah volume residu lambung pasien-pasien kritis yang terpasang nasogastric tube.

\section{DAFTAR PUSTAKA}

American Association of Critical Care Nurse (AACN). 2010. Family Visitation in The Adult Intensive Care Unit. AS: AACN

Dehghan M, Fatehi A, Mehdipoor R, et al. 2017. Does Abdominal Massage Improve Gastrointestinal Functions of Intensive Care Patients with an Endotracheal Tube?. Complementary Therapies in Clinical Practice; (30): 122-128

D. McClurg.S, Hagen. S, \& Hawkins. 2011. A Lowe Strong, Abdominal Massage for The Alleviation of Constipation Symptomps in People with Multiple Sclerosis: A Randomized Controlled Feasibility Study, Multscler; 17 (2)

Gacoin A, Camus C, Gros A, Isslame S, Chimot L, et al. 2010. In Long Term Ventilated Patients: Associated Factors and Impact on Intensive Care Unit Outcomes. Crit Care Med; 38 (10)

Kahraman Burcu B \& Ozdemir L. 2015. The Impact of Abdominal Massage Administered to Intubated and Enterally Fed Patients on The Development of Ventilator-Associated Pneumonia: A Randomized Controlled Study. International Journal of Nursing Studies 52: 519-524

Lamas K, Lindholm L, Engstrom B, \& Jacobsson C. 2010. Abdominal Massage for People with Constipation: A Cost Utility Analysis. J. Adv Nurs 66 (8): 1719-1729

Mohammadpour A, Sajadi M, Maghami S, et al. 2018. The Effect Gastric Gas Emptying on The Residual Gastric Volume in Mechanically-Ventilated Intensive Care Unit Patients Fed Through Nasogastric Tubes: A Randomized, Single-Blind, Clinical Trial. Asian Journal of Pharmaceutical and Clinical Research; 11 (9) 
Munawaroh S, Handoyo \& Astutiningrum. 2012. Efektivitas Pemberian Nutrisi Enteral Metide Intermittent Feeding \& Gravity Drip Terhadap Volume Residu Lambung pada Pasien Kritis di Ruang ICU RSUD Kebumen. Jurnal Ilmiah Kesehatan Keperawatan; 8 (3)

Setianingsih, Rahayu Y, Anna Anastasia. 2016. Analisis fakor-faktor yang berhubungan dengan gastric residual volume pada pasien yang mendapat nutrisi enteral metode bolus feeding di ruang ICU RSUD Tugurejo Semarang. Prosiding seminar ilmiah nasional keperawatan.

Sinclair M. 2011. The Use of Abdominal Massage to Treat Crhonic Constipation. J Bodyw Mov Ther. 15 (4): 436-445

Tekgunduz K, Gurol A, Apay A, et al. 2014. Effect of abdomen massage for prevention of feeding intolerance in preterm infants. Italian Journal of Pediatric.; 40 (1): 1.

Theresa A. 2010. Gastric Residuals - Understand Their Significance to Optimize Care. Today's Dietitian The Magazine for Nutrition Professionals Vol. 12 No. 5

Thomas. SS, Krishna. B \& Das.N. 2019. A study to assess the effectiveness of abdominal massage on gastric residual volume among patients with intermittent nasogastric tube feeding in a selected hospital, bangalore. IOSR Journal of Nursing and Health Science (IOSR-JNHS); 8 (4).

Uysal N. 2017. The effect of abdominal massage administered by caregivers on gastric complications oncurring in patients intermitten enteral feeding. European Journal of Integrative Medicine; (10): 75-81

Uysal N, Eser I \& Akpinar H. 2012. The Effect of Abdominal Massage on Gastric Residual Volume: A Randomized Controlled Trial. Gastroenterol Nurs 35 (2): $117-123$

Weijs PJ, Cynober L, Delegge M, Kreymann G, et al. 2014. Protein and amino acids are fundamental to optimal nutrition support in critically ill patients. Crit Care; 17; 18 (6): 59. 